AKSIOMA: Jurnal Program Studi Pendidikan Matematika

DOI: https://doi.org/10.24127/ajpm.v10i3.3702

\title{
BAGAIMANA BAHAN AJAR BERBASIS WEBSITE MEMBANTU MENINGKATKAN KEMAMPUAN BERPIKIR KRITIS MATEMATIS SISWA?
}

\author{
Khoerul Umam ${ }^{*}$, Ervin Azhar ${ }^{2}$ \\ ${ }^{1,2}$ Universitas Muhammadiyah Prof. DR. HAMKA, Jakarta, Indonesia \\ *Corresponding author \\ Email: khoerul.umam@uhamka.ac.id ${ }^{* 1)}$ \\ ervin.azhar.matematika@uhamka.ac.id ${ }^{2)}$
}

Received 30 April 2021; Received in revised form 08 September 2021; Accepted 24 September 2021

\begin{abstract}
Abstrak.
Pembelajaran matematika secara daring sangat menyulitkan guru dan siswa dalam melakukan banyak hal termasuk komunikasi langsung. Keterbatasan ini tidak boleh mengurangi kualitas pembelajaran matematika yang diberikan kepada siswa. Tujuan penelitian ini adalah menemukan alterantif pembelajaran yang dapat diimplementasikan secara praktis dalam pembelajaran matematika yang dapat mendorong siswa untuk meningkatkan kemampuan berpikir kritis matematis siswa. Subjek penelitian merupakan siswa yang berada di Kelas VIII sebanyak 40 siswa yang terdaftar pada sekolah menengah pertama swasta di Jakarta. Metode penelitian ini menggunakan metode penelitian kuantiatif . Analisis data penelitian ini akan dideskripsikan secara lebih jelas hasil pengembangan bahan ajar berbasis website dapat mendukung peningkatan kemampuan berpikir kritis matematis siswa. Hasil penelitian menunjukkan bahwa pengembangan bahan ajar berbasis website mampu menjembatani kesenjangan antara guru dan siswa. Bahan ajar yang dikembangkan dengan menggunakan website juga mampu meningkatkan kemampuan berpikir kritis matematis siswa.
\end{abstract}

Kata Kunci: Bahan ajar; kemampuan berpikir kritis; website; pembelajaran daring.

\begin{abstract}
Background. Learning mathematics online is very difficult for teachers and students to do many things including direct communication. This limitation should not reduce the quality of mathematics learning provided to students. The purpose of this study is to find learning alternatives that can be practically implemented in mathematics learning that can encourage students to improve students' mathematical critical thinking skills. The research subjects were students in Class VIII who were enrolled in private junior high schools in Jakarta. This research method uses quantitative research methods. Analysis of this research data will describe more clearly the results of the development of website-based teaching materials that can support the improvement of students' mathematical critical thinking skills. The results showed that the development of website-based teaching materials was able to bridge the gap between teachers and students. Teaching materials developed using the website are also able to improve students' mathematical critical thinking skills.
\end{abstract}

Key word: Critical Thinking Skills, Website, Online learning.

This is an open access article under the Creative Commons Attribution 4.0 International License

\section{PENDAHULUAN}

Bahan ajar matematika berbasis website meningkat secara signifikan dalam beberapa tahun belakangan ini
(Sojayapan \& Khlaisang, 2020; Khoerul Umam et al., 2019). Penggunaan bahan ajar digital berbasis website tidak lepas dari prilaku siswa yang sangat dekat 
dengan handphone dan laptop menjadi salah satu alasan banyak peneliti mengembangkan bahan ajar matematika. Akan tetapi, pengembangan bahan ajar matematika belum mengarahkan secara spesifik mengenai kemampuan berpikir kritis siswa. Padahal, pembelajaran matematika yang berorientasi pada peningkatan berpikir kritis berperan sangat penting. Penelitian-penelitian pendidikan matematika yang berfokus pada pengembangan kemampuan berpikir kritis telah banyak (Alim et al., 2015; Nurlaeli et al., 2018; K. Umam et al., 2019). Pentingnya kemampuan berpikir kritis bagi siswa karena memberikan dampak bagi siswa untuk beradaptasi dengan berbagai tantangan di masa mendatang. Kemampuan berpikir kritis menjadi tantangan yang sangat berat bagi siswa dalam proses belajar. Siswa belajar bagaimana menganalisis suatu permasalahan secara mandiri (Bunyamin et al., 2020; Septiany et al., 2015; Khoerul Umam et al., 2019). Siswa belajar bagaimana memutuskan suatu penyelesaian yang didasarkan atas informasiinformasi yang berguna. Kemampuan berpikir kritis ini berperan penting dalam membekali kesiapan siswa pada masa yang akan datang. Kemampuan berpikir kritis melatih siswa untuk berpikir secara lebih rasional, dan details berdasarkan analisis informasi-informasi yang dilakukan oleh siswa(DeWaelsche, 2015; Ikram et al., 2021; Rahaju et al., 2019; Yaldiz \& Bailey, 2019).

Kemampuan siswa untuk berpikir secara kritis menjadi aspek fundamental untuk pembelajaran matematika. Berpikir kritis memberikan kesempatan bagi siswa untuk mengembangkan kemampuan berpikirinya. Kemampuan berpikir kritis matematis dalam belajar matematika telah memberikan kesempatan bagi siswa untuk berkembang secara berkelanjutan(Fahim \& Pezeshki, 2012; Kosiret et al., 2021). Contohnya; ketika siswa belajar bagaimana memutuskan secara mandiri tentang langkah-langkah penyelesaian dari suatu permasalahan matematis. Keputusan langkah-langkah penyelesaian suatu masalah yang dipilih oleh siswa, diawali bagaimana siswa mengindentifikasi suatu masalah. Siswa belajar menganalisis informasi-informasi apa saja yang dibutuhkan dan dapat membantu menyelesaikan masalah matematis. Kemampuan siswa untuk menganalisis suatu masalah membantunya untuk memahami masalah matematis(Fadilah, 2021; Ikram \& Ikram, 2021).

Pada saat siswa berhasil memetakan informasi-informasi yang penting atas dasar analisis permasalahan matematis (Utami \& Bharata, 2020). Siswa diminta untuk mengkorelasikan informasiinformasi tersebut dengan teoremateorema, dan konsep matematika. Kemampuan siswa untuk menghubungkan antara berbagai informasi memberikan siswa mengembangkan interkorelasional matematis sehingga dapat membantu siswa untuk memutuskan suatu langkah penyelesaian masalah matematis(Maričić \& Špijunović, 2015; Yacoubian, 2015). Langkah - langkah penyelesaian yang telah dipilih oleh siswa merupakan langkah penting dalam proses pembelajaran matematis. Dalam konteks ini, orisinalitas penentuan langkah penyelesaian yang dibuat oleh siswa dapat dengan mudah dievaluasi. Evaluasi dapat dilakukan dengan memberikan pertanyaan "Mengapa" dan meminta siswa untuk menjelaskan langkah tersebut. Ketika siswa secara tegas dapat memberikan alasan yang logis mengapa menentukan 
langkah-langkah tersebut dan bukan didasarkan hasil imitasi dari teman sejawatnya, maka dapat dipastikan bahwa siswa tersebut memiliki kemampuan berpikir kritis matematis.

Langkah - langkah yang telah dijelaskan di atas, dapat dengan mudah dievaluasi secara bertahap ketika pembelajaran matematika berlangsung secara tatap muka. Guru dapat berinteraksi langsung dengan siswa dan siswa juga secara instan mendapatkan umpan balik yang sesuai kesulitan yang dialami. Akan tetapi, pembelajaran matematika pada masa pandemic COVID-19 telah mengubah landscpace pembelajaran matematika dari tatap muka menjadi virtual (Nabilah et al., 2021). Tantangan terberat dari pembelajaran matematika pada kelas virtual yaitu bagaimana mekanisme kontrol guru atas pembelajaran matematika yang dilakukan oleh siswa. Pembelajaran matematika yang tidak memberikan tantangan berdampak pada tidak adanya kesempatan bagi siswa untuk berpikir secara kritis (Fahim \& Pezeshki, 2012; Kurniasih \& Muchlis, 2021; W. Lee et al., 2013; Rahaju et al., 2019). Hal ini menyebabkan siswa kesulitan dalam mengembangkan kemampuan berpikir kritisnya.

Beberapa penelitian sebelumnya, telah melakukan penelitian mengukur tingkat keefektifan pembelajaran matematika secara interaktif. Namun, beberapa penelitian-penelitian di atas, belum ada yang meneliti efektifitas media pembelajaran yang mampu mengembangkan kemampuan berpikir kritis siswa yang dilakukan secara virtual sepenuhnya. Pandemi COVID-19 ini telah memaksa pembelajaran matematika yang harus dilakukan secara virtual demi mencegah penyebaran virus COVID-19. Sejalan dengan kebutuhan dasar akan kemampuan berpikir kritis bagi siswa, maka penelitian ini bertujuan untuk mengetahui efektifitas pengembangan bahan ajar berbasis website yang dikembangkan untuk meningkatkan kemampuan berpikir kritis matematis siswa.

\section{Pembelajaran Matematika Berbasis Website}

Pembelajaran matematika berbasis website telah banyak dikembangkan dengan beragam model cara (Bakker et al., 2017; Zhang \& Wu, 2016b). Pembelajaran matematika yang disampaikan dengan website Tujuan utama dari pembelajaran berbasis website ini diantaranya yaitu; memberikan layanan pembelajaran matematika berbasis website. Dengan adanya pandemi COVID-19 ini, pembelajaran tatap muka sudah ditiadakan. Webiste memberikan solusi alteranatif dalam proses pembelajaran matematika. Guru dapat menggunakan berbagai aplikasi yang sudah banyak dikembangkan baik dengan menggunakan Google Classroom, Schoology, dan Moodle (Hastuti et al., 2021; Zhang \& Wu, 2016a). Pemilihan website yang digunakan dalam pembelajaran sangat bergantung pada kebijakan sekolah dan kemampuan digital guru tersebut. Dalam konteks penelitian ini menggunakan aplikasi Moodle yang sudah dimodifikasi oleh tim IT sekolah.

Pembelajaran matematika berbasis website mendukung terciptanya lingkungan pembelajaran yang interaktif pada basis digital. Keaktifan siswa dalam pembelajaran berbasis website dapat dengan mudah diidentifikasi melalui kolom komentar baik pada saat penyampaian materi dan forum diskusi. Pada penyampaian materi, komentar komentar siswa menggambarkan 
keingintahuan siswa terhadap materi yang disampaikan (Bakker et al., 2017; Naserly, 2020). Lain halnya dengan forum diskusi yang memberikan kesempatan pada seluruh siswa untuk berargumentasi sesuai dengan pemahaman yang sudah terbentuk. Pada saat forum diskusi dilakukan, penelitian ini mewajibkan siswa untuk memberikan komentar baik siswa tersebut memahami materi ataupun tidak. Hal ini dilakukan sebagai landasan untuk tim peneliti untuk menganalisis sejauhmana kemampuan berpikir kritis matematis siswa berkembang. Hasil analisis ini yang akan menjadi landasan utama dalam perbaikan - perbaikan kualitas pembelajaran matematika pada pertemuan pertemuan selanjutnya (Bunyamin et al., 2020; Khoerul Umam, 2018). Keterbukaan antar siswa dan guru dalam proses pembelajaran mengeliminasi jarak sehingga siswa merasa nyaman dalam memberikan argumentasi. Sebaliknya, guru juga merasa senang dengan tingkat partisipasi siswa yang meningkat dalam pembelajaran matematika. Guru juga dapat memberikan arahan ketika argumentasi yang disampaikan oleh siswa kurang relevan.

\section{Kemampuan Berpikir Kritis Matematis}

Kemampuan berpikir kritis matematis berperan penting dalam proses pembelajaran matematika saat ini. Tantangan masa depan yang tidak mudah untuk dipahami memerlukan kemampuan berpikir kritis (DeWaelsche, 2015; Saida et al., 2021). Dalam konteks pembelajaran matematika saat ini, biasanya siswa hanya dijelasakan tentang rumus matematika dan mendorong siswa untuk menyelesaikan masalah sesuai dengan contoh yang diberikan oleh guru. Kebiasaan pembelajaran matematika seperti itu tidak memberikan kesempatan untuk siswa berkembang dan meningkat-kan kemampuan berpikir kritis matematisnya (Heidari \& Shahbazi, 2016; Hendryawan et al., 2017; Yacoubian, 2015).

Dalam konteks pembelajaran matematis yang mendukung kemampuan berpikir kritis, pembelajaran matematika perlu mendorong untuk penyelesaian masalah matematika. Masalah matematika yang diberikan kepada siswa bersifat kontekstual yang mendorong siswa untuk berpikir (Kim \& Choi, 2014; Kusaeri \& Aditomo, 2019). Pada saat siswa menemukan masalah matematika, siswa tidak langsung mengerjakan akan tetapi membutuhkan kemampuan mengindentifikasi masalah. Informasi - informasi yang telah identifikasi selanjutnya dianalisis oleh siswa dengan cara menghubungkan satu informasi dengan informasi yang lainnya(Kusaeri \& Aditomo, 2019; Zimeri, 2016). Kemampuan siswa untuk menganalisis situasi dari masalah berperan signifikan terhadap kemampuankemampuan lainnya(Marni Silvia; Suyono; Roekhan; Titik Harsiati, 2019; Schukajlow et al., 2015; Sinclair et al., 2011). Kemampuan siswa untuk mengkorelasikan informasi-informasi dari masalah dijadikan dasar utama bagi siswa untuk memahami dan menyusun rencana penyelesaian suatu masalah.

\section{METODE PENELITIAN}

Jenis penelitian ini yang dilakukan termasuk kategori penelitian kuantitatif dengan menggunakan one grouped pretest posttest design(Safrina et al., 2014). Desain penelitian ini tidak menggunakan kelas lain sebagai pembanding pada kelas yang terimplementasi pembelajaran matematika berbasis website. Akan tetapi, penelitian ini menggunakan tes awal 
sehingga peneliti dapat dengan mengetahui sebesar apa pengaruh yang ditimbulkan dari hasil pengembangan pembelajaran matematika berbasis website ini dapat meningkatkan kemampuan berpikir kritis siswa. Penelitian ini dilakukan di Sekolah Menengah Pertama Swasta, Jakarta Timur pada semester Ganjil 2020/2021. Pembelajaran matematika dilakukan secara daring dengan bantuan Google Classroom.

Populasi penelitian ini adalah peserta didik kelas VIII SMP Swasta di Jakarta. Jumlah sampel yang dipilih sebanyak 40 orang. Adapun beberapa informasi terkait subjek penelitian dapat dilihat pada Tabel 1.

Tabel 1. Demografi subjek penelitian

$\begin{array}{lcc}\begin{array}{l}\text { Kategori } \\ \text { Gender }\end{array} & \text { N } & \text { Persentase } \\ \text { - Laki-laki } & 21 & 53 \% \\ \text { - Perempuan } & 19 & 47 \%\end{array}$

\section{Alat pembelajaran saat ini}

$\begin{array}{lcc}\text { - Laptop } & 9 & 22 \% \\ \text { - Handphone } & 12 & 30 \% \\ \text { - Laptop dan } & 19 & 48 \%\end{array}$

Handphone

\section{Koneksi internet yang digunakan}

\begin{tabular}{lcc} 
- Wifi & 32 & $80 \%$ \\
- Data Seluler & 8 & $20 \%$ \\
\hline
\end{tabular}

Penelitian ini menggunakan teknik pengambilan sampel purposive. Hal ini karena penentuan sampel dilakukan dengan pertimbangan tertentu. Pertimbangan saran guru menjadi pertimbangan utama dalam penentuan sampel penelitian ini. Penelitian ini secara khusus mengangkat materi persamaan aljabar.
Teknik pengumpulan data dilakukan dengan 2 cara yaitu Teknik tes dan Non tes. Teknik tes dilakukan dengan tujuan agar dapat mengukur kemampuan berpikir kritis matematis siswa yang sesuai dengan indikator-indikator berpikir kritis matematis. Sedangkan teknik non tes digunakan untuk mengevaluasi respons siswa terhadap media pembelajaran yang

Dalam rangka melihat sejauhmana kontribusi penelitian dalam mendukung kemampuan berpikir kritis, penelitian menggunakan instrumen kemampuan berpikir kritis siswa dan instrument evaluasi bahan ajar. Instrumen berpikir kritis siswa dikembangkan dengan mengadaptasi dari soal Ujian Nasional. Instrumen evaluasi pembelajaran dikembangkan dengan mengadopsi dari penelitian (DeWaelsche, 2015; Wongsila \& Yuenyong, 2019).

Data yang telah terkumpul selanjutnya akan dianalisis menggunakan 2 cara yaitu analisis inferensial dan analisis deskriptif. Analisis inferensial akan dilakukan dengan melakukan uji Ngain, uji normalitas, uji homogenitas, dan uji t-test (Paired Sample T-test).

Penentuan kriteria kualitatif berpikir kritis ditetapkan berdasarkan perolehan persentase skor yang telah dikonversikan menjadi 4 kriteria yaitu sangat baik, baik, cukup, dan kurang baik. 4 kriteria tersebut akan menjadi acuan untuk peneliti dalam mengevaluasi berpikir kritis siswa. Untuk lebih jelasnya, dapat dilihat pada Tabel 2 (Susandi, 2020) .

Tabel 2. Kriteria kualitatif berpikir kritis

\begin{tabular}{cc}
\hline Interval & Kriteria \\
\hline $81.25 \%<x \leq 100 \%$ & Sangat Baik \\
$81.25 \%<x \leq 100 \%$ & Baik \\
$81.25 \%<x \leq 100 \%$ & Kurang Baik \\
$81.25 \%<x \leq 100 \%$ & Tidak Baik \\
\hline
\end{tabular}


Analisis inferensial dilakukan dengan beberapa uji statistika. Pertama, siswa diberikan tes awal mengenai masalah matematika. Pemberian tes awal (pretest) ini bertujuan untuk mengetahui kemampuan awal berpikir kritis matematis siswa sebelum menerapkan pembelajaran berbasis website. Dalam mengevaluasi efektifitas pengembangan bahan ajar dapat dilihat melalui hasil prestest dan posttest yang telah dianalisis dengan menggunakan uji $\mathrm{t}$ dan $\mathrm{N}$-gain. Beberapa hipotesis yang dapat disusun, yaitu:

$\mathrm{H}_{0} \quad$ : tidak terdapat perbedaan signifikan sebelum dan sesudah menerapkan hasil pengembangan bahan ajar.

$\mathrm{H}_{1} \quad$ : terdapat perbedaan signifikan sebelum dan sesudah menerapkan hasil pengembangan bahan ajar.

Tahap kedua, melakukan uji N-Gain untuk mengetahui peningkatan kemampuan berpikir kritis siswa sebelum dan sesudah menggunakan hasil pengembangan bahan aja. Kriteria efektifitas disesuaikan dengan kriteria $\mathrm{N}$-Gain oleh Meltzer (2002).

Tabel 3. N-Gain

\begin{tabular}{cc}
\hline $\mathbf{N}-$ Gain & Kriteria \\
$\mathbf{N}-$ Gain $<\mathbf{4 0}$ & Tinggi \\
$\mathbf{4 0} \leq \mathbf{N}-$ Gain $<\mathbf{7 5}$ & Sedang \\
$\mathbf{N}-$ Gain $\geq \mathbf{7 5}$ & Rendah \\
\hline
\end{tabular}

Tahap ketiga, uji homogenitas dan normalitas. Hasil yang diperoleh selanjutnya akan digunakan sebagai uji prasyarat Paired Sampel T-test melalui uji Kolmogorov-Smirnov. Hasil Lavene test digunakan sebagai uji prasyarat Paired Sampel T-test melalui uji Lavene test.
Tahap keempat, melakukan uji paired sampel T-test. Uji ini dilakukan dengan tujuan untuk mengetahui ada atau tidaknya perubahan nilai rata-rata yang siginifikan dari sebelum dan setelah menggunakan bahan ajar. Seluruh tahapan analisis data dalam penelitian ini menggunakan aplikasi SPSS 26.

\section{HASIL DAN PEMBAHASAN}

Hasil penelitian ini dapat dipresentasikan dalam dua jenis yaitu analisis deskriptif dan analisis inferensial. Analisis deskriptif akan menjelaskan hasil survey tentang bagaimana respons siswa terhadap pengembangan pembelajaran matematika berbasis website. Analisis inferensial digunakan dengan tujuan utama yaitu mengetahui peningkatan kemampuan berpikir kritis siswa yang dibandingkan berdasarkan hasil pretest dan posttest.

\section{Respons Peserta Didik}

Dalam mendeskripsikan bagiamana pembelajaran matematika berbasis website in dapat meningkatkan kemampuan berpikir kritis matematis siswa. Pada akhir pertemuan, siswa diminta untuk mengisi survey sebagai bagian dari evaluasi diri atas pembelajaran yang sudah berlangsung(Bjørndal, 2020; Galbraith \& Stillman, 2006; Kreber \& Castleden, 2009). Survey terdiri dari 2 apsek yaitu aspek penyampaian materi dan berpikir kritis. Untuk lebih jelas melilhat respons siswa dari kedua aspek tersebut dapat di lihat pada Tabel 4. 
AKSIOMA: Jurnal Program Studi Pendidikan Matematika

DOI: https://doi.org/10.24127/ajpm.v10i3.3702

Tabel 4 Response siswa terhadap materi yang sudah diberikan

\begin{tabular}{|c|c|c|c|c|}
\hline No & Aspek & Respon Siswa & Mean & SD \\
\hline \multirow[t]{5}{*}{1} & Penyampaian & Materi yang disampaikan mudah dipahami & 4.07 & 0.26 \\
\hline & Materi & $\begin{array}{l}\text { Materi yang disebarluaskan menggunakan bahasa } \\
\text { yang sederhana }\end{array}$ & 4.36 & 0.48 \\
\hline & & Penjelasan materi disampaikan secara details & 4.57 & 0.49 \\
\hline & & Materi - materi yang disampaikan sangat kontekstual & 4.93 & 0.26 \\
\hline & & $\begin{array}{l}\text { Dengan membaca materi, saya sudah bisa memahami } \\
\text { konsep yang akan dipelajari. }\end{array}$ & 4.64 & 0.48 \\
\hline \multirow[t]{6}{*}{2} & Berpikir & Materi yang disampaikan pada website & 4.29 & 0.59 \\
\hline & & $\begin{array}{l}\text { membutuhkan analisis sederhana dan menyenangkan } \\
\text { Masalah matematika yang diberikan sering saya } \\
\text { temukan di kehidupan sehari - hari sehingga saya } \\
\text { bisa berargumentasi }\end{array}$ & 4.07 & 0.46 \\
\hline & & $\begin{array}{l}\text { Materi yang dipelajari mendorong saya untuk } \\
\text { menemukan pokok permasalahan yang sebenarnya }\end{array}$ & 4.64 & 0.48 \\
\hline & & $\begin{array}{l}\text { Materi yang disampaikan mendorong saya untuk } \\
\text { berpikir secara kritis }\end{array}$ & 4.64 & 0.61 \\
\hline & & $\begin{array}{l}\text { Masalah matematika yang diberikan menuntut saya } \\
\text { untuk banyak memberikan argumentasi - } \\
\text { argumentasi. }\end{array}$ & 4.50 & 0.50 \\
\hline & & $\begin{array}{l}\text { Setelah belajar matematika di website, saya menjadi } \\
\text { lebih mudah berargumentasi secara realistis. }\end{array}$ & 4.43 & 0.49 \\
\hline
\end{tabular}

Pada aspek penyampaian materi, siswa merespons dengan baik hasil pengembangan bahan ajar berbasis website ini, hal ini dapat terlihat dari aspek yang diukur diantaranya "Materi yang disampaikan mudah dipahami" mendapatkan rata-rata sebesar 4.07 dengan standar deviasi 0.26. Aspek ini menunjukkan bahwa pengembangan bahan ajar matematika yang sudah dilakukan berhasil mempermudah penyampaian materi matematika. Siswa merespons dengan sangat senang. Hal ini juga dapat dilihat pada aspek "Materi materi yang disampaikan sangat kontekstual" yang mendapatkan rata-rata respons 4.93 dengan standar deviasi 0.26. Tanggapan positif siswa terkait dengan kontekstualitas materi matematika dipadukan dengan penyajian materi yang sederhana dan terintegrasi mampu menarik siswa untuk belajar matematika menjadi lebih semangat.

\section{Kemampuan Berpkir Kritis}

Dalam mengevaluasi efektifitas pengembangan bahan belajar matematika dapat dilakukan melalui beberapa hasil uji kemampuan berpikir kritis. Tim peneliti mengawali uji deskriptif kuantitatif menggunakan data tes awal dan tes akhir terhadap efektifitas pembelajaran matematika. Data pretest dan posttest dapat dilihat lebih jelas pada Tabel 5 . 
DOI: https://doi.org/10.24127/ajpm.v10i3.3702

Tabel 5. Hasil deskriptif dari pretest dan posttest

\begin{tabular}{lccc} 
Jenis Data & Min & Max & Rata-rata \\
\hline Pretest & 60 & 100 & 79,81 \\
posttest & 64 & 100 & 83,00 \\
\hline
\end{tabular}

Berdasarkan data yang telah diperoleh sangat terlihat jelas bahwa terdapat peningkatakan yang signifikan antara rata-rata data pretest dan data posttest. Peningkatan rata-rata kemampuan berpikir kritis siswa ini menunjukkan bahwa proses pembelajaran matematika berbasis website dapat memberikan kontibusi positif terhadap peningkatan kemampuan berpikir kritis siswa. Hal senada juga disampaikan oleh Septiany et al., (2015) pembelajaran dengan menggunakan website terbukti secara empiris dapat meningkatkan kemampuan berpikir kritis siswa. Fasilitas yang sudah dikembangkan dari berbagai bidang keilmuan pada aplikasi yang digunakan memberikan kualitas pembelajaran matematika berbasis website dapat mendukung berpikir kritis siswa (K.-T. Lee \& Duncan-Howell, 2007; Naserly, 2020; Khoerul Umam et al., 2019). Kedua, menghitung $N$-gain dari hasil pretest dan posttest. Hasil $N$-gain selanjutnya akan dikategori menjadi tiga yaitu rendah, sedang dan tinggi. Untuk mengidentifikasi hasil $N$-gain dapat dilihat pada Tabel 6 .

Tabel 6. Kriteria $N$-Gain nilai pretest dan \begin{tabular}{lcc} 
posttest & & \\
\multicolumn{1}{c}{ Data } & Rata-rata N-gain & Kategori \\
\hline Eksperimen & 75,91 & Efektif \\
\hline Kontrol & $-33,32$ & Tidak efektif \\
\hline
\end{tabular}

Rata-rata $N$-gain dari data pada Tabel 6 menunjukkan hasil sebesar 75,91.
Hal ini menunjukkkan bahan pengembangan bahan ajar matematika yang telah dilakukan termasuk kategori sedang. Berdasarkan evaluasi yang dilakukan, siswa masih kesulitan dalam pembelajaran dengan durasi video penjelasan panjang. Ketiga, melakukan uji normalitas dengan Kolmogorov. Peneliti menguji normalitas berdasarkan 3 data yaitu hasil rata-rata nilai pretest, posttest, dan $\mathrm{N}$-gain. Hasil uji normlitas dapat dilihat pada Tabel 7 .

Tabel 7 Uji normalitas kolmogorov smirnov

\begin{tabular}{cc}
\hline Aspek & Sig* \\
\hline Eksperimen & 0.047 \\
\hline Kontrol & 0.034 \\
\hline N-gain eksperimen & 75.91 \\
\hline N-gain kontrol & -33.32 \\
\hline *signifikansi level 0.05 &
\end{tabular}

Tabel 7 menunjukkan data uji normalitas pada kelas eksperimen (0.047) dan kontrol (0.034) di bawah signifikansi level 0,05 sehingga kedua data tersebut dapat dikategorikan terdisribusi secara normal.

Keempat, melakukan uji homogenitas dengan menggunakan Lavene test. Uji yang dilaksanakan ini mengevaluasi apakah data bersifat homogen atau tidak. Dari hasil uji homogenitas data yang ada menunjukkan bahwa data yang bersifat homogen, yaitu memperoleh nilai .sig sebesar 0,436 (>0,05 atau > $\alpha)$.

Kelima, melakukan uji paired T-test. Uji paired T-test ini bertujuan untuk mengetahui apakah pengembangan bahan ajar yang dilakukan dapat meningkatkan kemampuan berpikir kritis siswa. Selain itu, uji ini juga dapat memberikan informasi perbedaan antara rata-rata kelas eksperimen dan kelas kontrol. 
DOI: https://doi.org/10.24127/ajpm.v10i3.3702

Adapun hasil dari uji paired sample T-test, yaitu diperoleh nilai Sig (2-tailed) sebesar $0,044 \quad(<0,05)$. Hal ini menunjukkan bahwa terdapat perbedaan rata-rata yang signifikan antara kelas eksperimen dan kelas kontrol. Pengembangan bahan ajar matematika berbasis website yang digunakan dalam proses pembelajaran terbukti secara empiris dapat meningkatkan kemampuan berpikir kritis matematis siswa.

Setelah belajar matematika dengan menggunakan bahan ajar berbasis website, siswa mengalami peningkatan kemampuan berpikir kritisnya. Hal ini sejalan dengan penelitian Fathurrohman et al., (2014), Maharaj et al., (2015), Sojayapan \& Khlaisang, (2020), dan Khoerul Umam et al., (2019) yang menyatakan bahwa pembelajaran matematika dengan bahan ajar berbasis website dapat meningkatkan kemampuan berpikir siswa, dan minat anak dalam proses belajar. Dengan mendekatkan pembelajaran matematika pada handphone dan laptop yang memang dekat dengan siswa, maka bahan ajar matematika berbasis website tentu dapat dengan mudah diakses oleh siswa melalui handphone dan laptop. Dengan kemudahan akses, siswa bisa belajar matematika dengan waktu lebih banyak. Secara spesifik, penelitian ini memberikan kontribusi bahwa kemampuan berpikir kritis matematis siswa dapat ditingkatkan salah satunya dengan mengembangkan bahan ajar matematika berbasis website.

Penerapan pembelajaran matematika dengan bantuan bahan ajar berbasis website tidak hanya memudahkan siswa dalam belajar matematika, akan tetapi guru juga akan merasa terbantu. Hal ini karena bahan ajar matematika berbasis website menyediakan berbagai teknologi yang dapat menilai dan mengevaluasi pemahaman matematis siswa secara online.

\section{KESIMPULAN DAN SARAN}

Pengembangan bahan ajar matematika berbasis website memberikan manfaat yang banyak bagi siswa. Hal ini tercermin dengan kemudahan akses yang didapatkan oleh siswa untuk mengakses materi-materi yang dipelajari. Hal ini didukung oleh komitmen guru yang telah mengunggah materi sebelum pembelajaran berlangsung dan mempersiapkan berbagai bahan evaluasi yang dapat terakses secara mudah. Materi yang disampaikan sangat mudah dipahami oleh siswa karena menggunakan bahasa yang sederhana. Masalah-masalah matematika yang dipresentasikan pada materi mendorong para siswa untuk berargumentasi baik secara tertulis maupun komunikasi. Siswa berargumentasi secara tertulis dengan memberikan komentar-komentar pada kolom yang telah disediakan pada website. Argumentasi secara langsung juga dapat siswa berikan ketika pembelajaran matematika dilakukan dengan menggunakan online meeting.

Kemampuan siswa dalam memberikan argumentasi-argumentasi dari pembelajaran yang telah berlangsung ini didukung oleh peningkatan kemampuan analisis masalah siswa. Kemampuan analisis masalah siswa mengalami peningkatan secara bertahap setelah pertemuan ketiga. Hal ini disebabkan materi yang disampaikan dalam permasalahan yang sangat dekat dengan kehidupan siswa. Hal ini menambah daya Tarik siswa untuk menganalisis situasi walaupun pelajaran yang sedang dipelajari adalah matematika. Pendekatan masalah kontekstual pada pengembangan bahan ajar berbasis website ini sesuai dengan tujuan utama 
dari penelitian ini yaitu meningkatkan kemampuan berpikir kritis siswa. Hasil penelitian telah menunjukkan bahwa adanya peningkatan kemampuan berpikir kritis matematis siswa yang belajar matematika dengan bantuan website.

Penelitian selanjutnya dapat mengeksplorasi bagaimana sikap dan respons siswa terhadap bahan ajar berbasis website pada pembelajaran matematika. Respons positif dan negatif siswa sangat mempengaruhi pencapaian tujuan pembelajaran matematika. Jika siswa mampu mengatur waktu pembelajaran dan menyelesaikan tugas secara mandiri di rumah, maka pencapaian pembelajaran dapat tercapai. Akan tetapi, jika respons dan sikap siswa tidak peduli dan tidak mengatur dengan baik jadwal kegiatannya, maka akan sulit mencapai tujuan pembelajaran matematika walaupun sudah difasilitasi bahan pembelajaran berbasis website. Oleh karena itu, respons siswa menjadi kunci utama dalam kesuksesan pencapaian standar pembelajaran matematika secara daring.

\section{DAFTAR PUSTAKA}

Alim, E. S., Umam, K., \& Rohim, S. (2015). Integration of reciprocal teaching-ICT model to improve students' mathematics critical thinking ability. Workshop Proceedings of the 23rd International Conference on Computers in Education, ICCE 2015.

Bakker, A., Ben-Zvi, D., \& Makar, K. (2017). An inferentialist perspective on the coordination of actions and reasons involved in making a statistical inference. Mathematics Education Research Journal, 29(4), 455-470. https://doi.org/10.1007/ s13394-016-0187-x
Bjørndal, C. R. P. (2020). Student teachers' responses to critical mentor feedback: A study of face-saving strategies in teaching placements. Teaching and Teacher Education, 91, 103047.

https://doi.org/10.1016/j.tate.2020.10 3047

Bunyamin, B., Umam, K., \& Lismawati, L. (2020). Critical Review of MLearning in Total Quality Management Classroom Practice in an Indonesian Private University. International Journal of Interactive Mobile Technologies (IJIM), 14(20), 76-90.

https://doi.org/10.3991/ijim.v14i20.1 5141

DeWaelsche, S. A. (2015). Critical thinking, questioning and student engagement in Korean university English courses. Linguistics and Education, 32, 131-147. https://doi.org/10.1016/j.linged.2015. 10.003

Fadilah, I. (2021). Analisis Kemampuan Pemahaman Konsep Matematis Siswa Kelas V Pada Materi Kubus Dan Balok Analisis Kemampuan Pemahaman Konsep Matematis Siswa Kelas V Pada Materi Kubus Dan Balok. International Journal of Progressive Mathematics Education, l(2), 160-183. https://doi.org/10.22236/ijopme.v1i1. 7308

Fahim, M., \& Pezeshki, M. (2012). Manipulating Critical Thinking Skills in Test Taking. International Journal of Education, 4(1), 153-160. https://doi.org/10.5296/ije.v4i1.1169

Fathurrohman, M., Porter, A., \& Worthy, A. L. (2014). Comparison of performance due to guided 
DOI: https://doi.org/10.24127/ajpm.v10i3.3702

hyperlearning, unguided hyperlearning, and conventional learning in mathematics: An empirical study. International Journal of Mathematical Education in Science and Technology, 45(5), 682-692.

https://doi.org/10.1080/0020739X.20 13.868541

Galbraith, P., \& Stillman, G. (2006). A framework for identifying student blockages during transitions in the modelling process. ZDM International Journal on Mathematics Education, 38(2), 143162.

https://doi.org/10.1007/BF02655886

Hastuti, E. S., Eclarin, L., \& Dalam, K. K. S. (2021). Kecemasan Siswa Sekolah Menengah Pertama Menyelesaikan Masalah SPLDV Pada Kelas Virtual Dalam. International Journal of Progressive Mathematics Education, 1(1), 64-84. https://doi.org/10.22236/ijopme.v1i1. 6914

Heidari, M., \& Shahbazi, S. (2016). Effect of training problem-solving skill on decision-making and critical thinking of personnel at medical emergencies. International Journal of Critical Illness and Injury Science, 6(4), 182187. https://doi.org/10.4103/22295151.195445

Hendryawan, S., Yusuf, Y., Wachyar, T. Y., Siregar, I., \& Dwiyanti, W. (2017). Analisis Kemampuan Berfikir Kritis Matematis Siswa Smp Tingkat Rendah Pada Pembelajaran Berbasis Masalah Dengan Green's Motivational Strategies. Aksioma, 8(2), 50-58.

Ikram, M., \& Ikram, M. (2021). Analysis of The Occurrence of Reversible
Reasoning for Inverse Cases: A Case Study on The Subject Adjie. International Journal of Progressive Mathematics Education, 8435(1), 115.

https://doi.org/10.22236/ijopme.v1i1. 6635 To

Ikram, M., Purwanto, \& Parta, I. N. (2021). Analysis of The Occurrence of Reversible Reasoning for Inverse Cases: A Case Study on The Subject Adjie. International Journal of Progressive Mathematics Education, 1(1), 1-15. https://doi.org/10.22236/ijopme.v1i1. 6635

Kim, K. S., \& Choi, J. H. (2014). The relationship between problem solving ability, professional self concept, and critical thinking disposition of nursing students. International Journal of Bio-Science and BioTechnology, 6(5), 131-142. https://doi.org/10.14257/ijbsbt.2014. 6.5.13

Kosiret, A., Indiyah, F. H., \& Wijayanti, D. A. (2021). The Use of Generative Learning Model in Improving Students' Understanding of Mathematical Concepts of Al-Azhar 19 Islamic High School. International Journal of Progressive Mathematics Education, 1(1), 16-26. https://doi.org/10.22236/ijopme.v1i1. 6593

Kreber, C., \& Castleden, H. (2009). Reflection on teaching and epistemological structure: Reflective and critically reflective processes in "pure/soft" and "pure/hard" fields. Higher Education, 57(4), 509-531. https://doi.org/10.1007/s10734-0089158-9 
Kurniasih, N., \& Muchlis, A. (2021). Analisis Kemandirian Belajar Matematika Siswa SMA Kelas XI Selama Pembelajaran Jarak Jauh Analisis Kemandirian Belajar Matematika Siswa SMA Kelas XI Selama Pembelajaran Jarak Jauh. International Journal of Progressive Mathematics Education, 1(2), 117126.

https://doi.org/10.22236/ijopme.v1i2. 6568

Kusaeri, \& Aditomo, A. (2019). Pedagogical beliefs about Critical Thinking among Indonesian mathematics pre-service teachers. International Journal of Instruction, 12(1), 573-590. https://doi.org/10.29333/iji.2019.121 $37 \mathrm{a}$

Lee, K.-T., \& Duncan-Howell, J. (2007). How Do We Know E-Learning Works? Or Does it? E-Learning and Digital Media, 4(4), 482-496. https://doi.org/10.2304/elea.2007.4.4. 482

Lee, W., Chiang, C. H., Liao, I. C., Lee, M. L., Chen, S. L., \& Liang, T. (2013). The longitudinal effect of concept map teaching on critical thinking of nursing students. Nurse Education Today, 33(10), 1219-1223. https://doi.org/10.1016/j.nedt.2012.0 6.010

Maharaj, A., Brijlall, D., \& Narain, O. K. (2015). Improving Proficiency in Mathematics through Website-based Tasks: A Case of Basic Algebra. International Journal of Educational Sciences, $\quad 8(2), \quad 369-386$. https://doi.org/10.1080/09751122.20 15.11890259

Maričić, S., \& Špijunović, K. (2015). Developing Critical Thinking in
Elementary Mathematics Education through a Suitable Selection of Content and Overall Student Performance. Procedia - Social and Behavioral Sciences, 180(November 2014), 653-659. https://doi.org/10.1016/j.sbspro.2015. 02.174

Marni Silvia; Suyono; Roekhan; Titik Harsiati. (2019). Critical Thinking Patterns of First-Year Students in Argumentative Essay Received: 14 August 2019 Abstract Accepted : 30 August 2019 Keywords : To cite this article: Journal for the Education of Gifted Young Scientists, 7(September), 683-697.

Nabilah, E., Azhar, E., Purwanto, S. E., \& Nabilah, E. (2021). Kecemasan Siswa Dalam Menyelesaikan Masalah Modelling Matematika Pada Praktek Kelas Virtual. Internatioinal Journal of Progressive Mathematics Education, $\quad 1(1), \quad 41-60$. https://doi.org/10.22236/ijopme.vli1. 6595

Naserly, M. K. (2020). Implementasi Zoom, Google Classroom, Dan Whatsapp Group Dalam Mendukung Pembelajaran Daring (Online) Pada Mata Kuliah Bahasa Inggris. Jurnal Aksara Public, 4(2), 155-165.

Nurlaeli, N., Noornia, A., \& Wiraningsih, E. D. (2018). Pengaruh Model Pembelajaran Problem Based Learning Terhadap Kemampuan Berpikir Kritis Matematis Siswa Ditinjau Dari Adversity Quotient. FIBONACCI: Jurnal Pendidikan Matematika Dan Matematika, 4(2), 145.

https://doi.org/10.24853/fbc.4.2.145154

Rahaju, R., Purwanto, P., Parta, I. N., \& 
Rahardjo, S. (2019). Students' critical thinking skills in making mathematical problems. Journal of Physics: Conference Series, 1318(1). https://doi.org/10.1088/17426596/1318/1/012094

Safrina, K., Ikhsan M, \& Ahmad, A. (2014). Peningkatan Kemampuan Pemecahan Masalah Geometri melalui Pembelajaran Kooperatif Berbasis Teori Van Hiele. Jurnal Didaktik Matematika, 1(1), 9-20. https://doi.org/10.24815/jdm.v1i1.12 38

Saida, A., Ikram, M., Saida, A., \& Ikram, M. (2021). Analysis of Students, Creative Thinking in Solving Cuboid Problems Analysis of Students , Creative Thinking in Solving Cuboid Problems. International Journal of Progressive Mathematics Education, 1(2), 104-116. https://doi.org/10.22236/ijopme.v1i2. 7307

Schukajlow, S., Krug, A., \& Rakoczy, K. (2015). Effects of prompting multiple solutions for modelling problems on students' performance. Educational Studies in Mathematics, 89(3), 393417. https://doi.org/10.1007/s10649015-9608-0

Septiany, V., Purwanto, S. E., \& Umam, K. (2015). Influence of learning on realistic mathematics ICT-Assisted mathematical problem solving skills students. Work-In-Progress Poster Proceedings of the 23rd International Conference on Computers in Education, ICCE 2015. Sinclair, M., Mamolo, A., \& Whiteley, W. J. (2011). Designing spatial visual tasks for research: The case of the filling task. Educational Studies in Mathematics, 78(2), 135-163. https://doi.org/10.1007/s10649-0119315-4

Sojayapan, C., \& Khlaisang, J. (2020). The effect of a flipped classroom with online group investigation on students' team learning ability. Kasetsart Journal of Social Sciences, 41(1), 28-33. https://doi.org/10.1016/j.kjss.2018.02 .003

Susandi, A. D. (2020). Pengembangan Model Pembelajaran M6 Untuk Meningkatkan Kemampuan Berpikir Kritis Matematika Siswa. In Disertasi (Vol. 1).

Umam, K., Nusantara, T., Parta, I. N., Hidayanto, E., \& Mulyono, H. (2019). An application of flipped classroom in mathematics teacher education programme. International Journal of Interactive Mobile Technologies, 13(3).

https://doi.org/10.3991/ijim.v13i03.1 0207

Umam, Khoerul. (2018). Peningkatan Kemampuan Berpikir Matematis Siswa melalui pembelajaran Reciprocal Teaching. Jurnal Pendidikan Matematika Indonesia, 3(2), 57-61.

Umam, Khoerul, Nusantara, T., Parta, I. N., Hidayanto, E., \& Mulyono, H. (2019). An Application of Flipped Classroom in Mathematics Teacher Education Programme. International Journal of Interactive Mobile Technologies (IJIM), 13(03), 68. https://doi.org/10.3991/ijim.v13i03.1 0207

Utami, P., \& Bharata, H. (2020). Analysis of Mathematical Critical Thinking Skill of Junior High School Students on the Two-Variable Linear Equation System. Journal of Physics: 
AKSIOMA: Jurnal Program Studi Pendidikan Matematika

DOI: https://doi.org/10.24127/ajpm.v10i3.3702

Conference Series, 1467(1). https://doi.org/10.1088/17426596/1467/1/012004

Wongsila, S., \& Yuenyong, C. (2019). Enhancing grade 12 students' critical thinking and problem-solving ability in learning of the STS genetics and DNA technology unit. Journal for the Education of Gifted Young Scientists, $\quad 7(2), \quad 215-235$. https://doi.org/10.17478/jegys.54900 5

Yacoubian, H. A. (2015). A Framework for Guiding Future Citizens to Think Critically About Nature of Science and Socioscientific Issues. Canadian Journal of Science, Mathematics and Technology Education, 15(3), 248260.

https://doi.org/10.1080/14926156.20 15.1051671

Yaldiz, N., \& Bailey, M. (2019). The Effect of Critical Thinking on Making the Right Decisions in the New Venture Process. Procedia Computer Science, 158, 281-286. https://doi.org/10.1016/j.procs.2019. 09.053

Zhang, Q., \& Wu, F. (2016a). State-ofthe-Art and Future Directions of Smart Learning. In State-of-the-Art and Future Directions of Smart Learning (Y. Li et a, pp. 257-261). Lecture Notes in Educational Technology.

https://doi.org/10.1007/978-981-287868-7

Zhang, Q., \& Wu, F. (2016b). Study on Teacher - Student Interaction in Flipped Classroom Based on Video Annotation Learning Platform. In Lecture Notes in Educational Technology (pp. 257-261). Springer, Singapore. https://doi.org/10.1007/978-981-287868-7

Zimeri, A. M. (2016). A flipped classroom exercise to teach undergraduates to critically think using primary scientific literature. International Journal of Environmental and Science Education, 11(12), 53965403. https://doi.org/10.15436/23786841.16 .914

\section{6}

